\title{
Notes on the Bangladesh calliphorid flies of medical importance (Insecta: Diptera) ${ }^{1)}$
}

\author{
Hiromu Kurahashi ${ }^{2)}$ and Qamar BanU") \\ 2) Department of Medical Entomology, National Institute of Health, \\ Shinagawa-ku, Tokyo 141, Japan \\ 3) Department of Zoology, University of Chittagong, Chittagong, Bangladesh
}

(Received: December 17, 1989)

Key words: blow flies, Bangladesh, Calliphoridae, Diptera, fauna, new record.

\begin{abstract}
A key is provided to the common species of the Bangladesh calliphorid flies. List of new localities, distributions and other ecological data are also recorded. The following twenty-one species were recorded for the first time from Bangladesh: Onesia khasiensis n. comb., Hemipyrellia ligurriens, Hypopygiopsis infumata, H. tumrasvini, Lucilia bismarckensis, L. papuensis, Phumosia indica, P. testacea, Bengalia torosa, B. labiata, Chrysomya chani, C. pinguis, Cosmina limbipennis, C. bicolor, Strongyloneura prolata, Isomyia oestracea, I. pseudonepalana, Rhyncomya setipyga, Idiella mandarina, I. divisa, Borbororhinia bivittata.
\end{abstract}

Taxonomical studies on muscoid flies in Bangladesh have not been conducted yet since Senior-White et al. published the Fauna of British India in 1940. Recently, fly surveys were programmed by the Toyama Medical and Pharmaceutical University Overseas Scientific Research Project and carried out by the authors in Bangladesh from May to June, 1989. A number of adult flies were collected from different parts of the country for taxonomic purposes. A simple key was prepared from these materials and some specimens collected by the other members of project team from September to October 1988. The present authors intended to describe the male of a little known species, Onesia khasiensis (Senior-White, 1923) n. comb. and illustrate the male genitalia hereinafter.

\section{Key to the subfamilies of Calliphoridae}

1. Metathoracic spiracle without distinct lappet usually with very small with marginal hairs; 4th longitudinal vein $(\mathrm{m})$ with evenly rounded bend; female postabdomen forming telescopic ovipositor; oviparous. No record from Bangladesh .......... . Subfamily Rhinophorinae

- Metathoracic spiracle with single large reniform lappet with dorsal opening; 4th longitudinal vein $(\mathrm{m})$ with evenly rounded bend; female postabdomen not forming telescopic ovipositor; larviparous. Neotropical fies ....... Subfamily Mesembrinellinae

1) This study was supported by the Grant-in-Aid for Monbusho International Scientific Research Program (Field Research) to the Toyama Medical and Pharmaceutical University in 1986, 1987 and 1988 (Grant No. 61042004, 62041036, 63041058). ZDSA Series No. 15.

2) 倉橋 弘：国立予防衛生研究所衛生昆虫部（テ141 東京都品川区上大崎 2-10-35） 
- Metathoracic spiracle with normal anterior and posterior lappets; 4th vein ( $\mathrm{m}$ ) with bend distinctly angulate; female postabdomen usually forming telescopic ovipositor, sometimes short in larviparous species; oviparous or larviparous $\ldots \ldots \ldots \ldots \ldots 2$

2. Stem vein with long fine setulae posteriorly on upper surface; subalar bulla sometimes

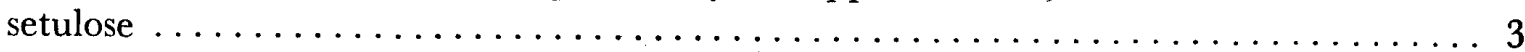

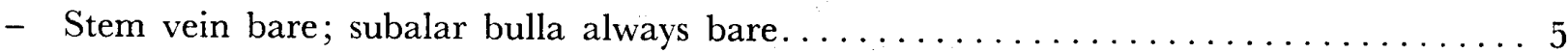

3. Thoracic squama bare above; subcostal sclerite with fine pubescence; subalar bulla

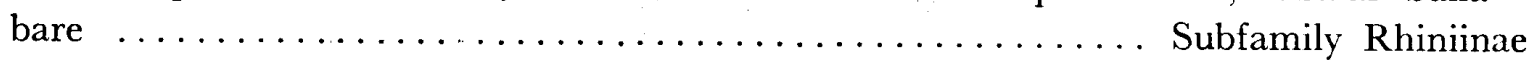

- Thoracic squama with hairy on upper surface; subcostal sclerite setulose; subalar bulla usually setulose (if bare, then metallic blue and yellow flies as in Eucompsomyia

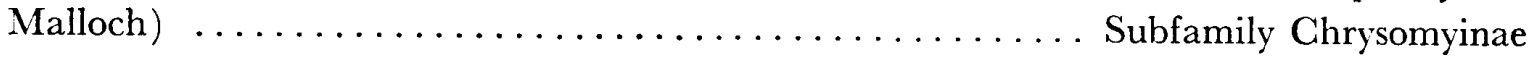

4. Anterior lappet of metathoracic spiracle with a conspicuous backwardly-directed tuft of long hairs; postscutellum forming a definite convex swelling which is microrugose and shows slight trace of shallow median incision; female postabdomen nontelescopic, modified for deposition of mature larvae ......... Subfamily Ameniinae

- Anterior lappet of metathoracic spiracle bare or at most with a very few small inconspicuous hairs; postscutellum region not at all convex or at most with rudimentary trace of swelling, not as above; female postabdomen forming a telescopic ovipositor, but sometimes short in larviparous species for deposition of first instar larvae Subfamily Calliphorinae

\section{Subfamily CALLIPHORINAE}

\section{Key to the genera of Calliphorinae}

1. Supraspiracular convexity clothed with long upstanding fine hair $\ldots \ldots \ldots \ldots \ldots 2$

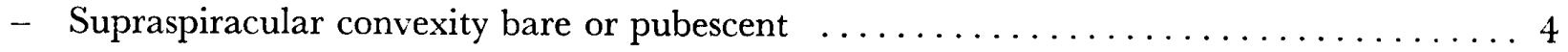

2. Body predominantly brilliant metallic green, blue or purple; subcostal sclerite covered

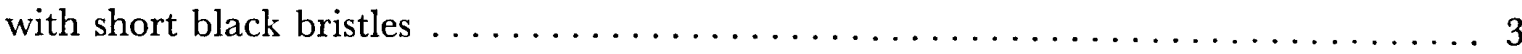

- Parts of thorax and base of abdomen testaceous; subcostal sclerite without jlack bristles or upstanding hair $\ldots \ldots \ldots \ldots \ldots \ldots \ldots \ldots \ldots$ Phumosia Robineau-Desvoidy

3. Legs in ô more or less fringed; hypopygium strongly developed; generally large flies, more than $15 \mathrm{~mm}$ in length $\ldots \ldots \ldots \ldots \ldots \ldots \ldots \ldots$ Hypopygiopsis Townsend

- Legs in $\hat{o}$ not fringed; hypopygium not strongly developed; generally small flies, not exceeding $12 \mathrm{~mm}$ in length .................... Hemipyrellia Townsend

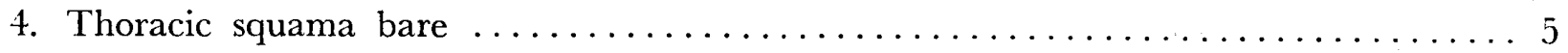

- Thoracic squama with hairs on disc or with a patch of small setulae towards inner

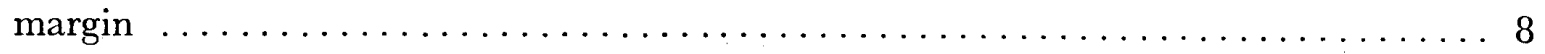

5. Brilliant shining green, blue or purple flies $\ldots \ldots \ldots \ldots \ldots \ldots \ldots \ldots \ldots \ldots \ldots$

- Brownish flies; sternopleural bristles 1+1; pleura without soft white hairs, but covered with long yellow, brown and black setulae; vibrissae generally inserted well above oral margin; arista long plumose to tip; no facial carina; eyes widely separated in $\hat{\delta}$; prosternum hairy; propleura bare except around the propleural bristle ....... $\ldots \ldots \ldots \ldots \ldots \ldots \ldots \ldots \ldots \ldots \ldots \ldots \ldots \ldots \ldots \ldots \ldots \ldots \ldots$ Bengalia Robineau-Desvoidy

6. Propleura and prostenum bare; postsutural $d c$ usually 4 , sometimes $3 \ldots \ldots \ldots$. ......... Subfamily Ameniinae, Tribe Catapicephalini, Catapicephala Macquart

- Propleura and prosternum hairy, postsutural $d c 3 \ldots \ldots \ldots \ldots \ldots \ldots \ldots$ 
7. Upper half of parafacialia bare; posterior parasquamal tuft developed $\ldots \ldots \ldots \ldots \ldots \ldots \ldots \ldots \ldots \ldots \ldots \ldots \ldots \ldots \ldots \ldots \ldots \ldots$ Lucilia Robineau-Desvoidy

- Upper half of parafacialia hairy; posterior parasquamal tuft absent $\ldots . \ldots \ldots \ldots$. Onesia Robineau-Desvoidy

8. Thoracic squama covered almost entirely or in part with hairs; eyes in $\hat{\delta}$ closely approximated, widely separated in $\$$; metallic flies generally bluish or with purple tinge. No record from Bangladesh ............. Calliphora Robineau-Desvoidy

- Thoracic squama with small patch of setulae; eyes in $\hat{o}$ nearly as widely separated as in 9 ; flies gray-dusted. No record from Bangladesh ......... Tainanina Villeneuve

\section{Genus Onesia Robineau-Desvoidy}

Onesia Robineau-Desvoidy, 1830, Essai Myod.: 365 (Type-species: Musca sepulcralis Meigen, 1826).

\section{Onesia (Melindopsis) khasiensis (Senior-White) n. comb.}

Nitellia khasiensis Senior-White, 1923, Mem. Dept. Agr. Ind., Ent. Ser. 7: 49.

Type-locality: Khasia Hills, Assam, India. Type and paratypes in the British Museum. Pollenia khasiensis: Senior-White, Aubertin and Smart, 1940: 119.

This species was previously included in the genus Pollenia by Senior-White et al. (1940). Examination of type material and one male in our collection revealed that it belongs to Melindopsis Kurahashi, 1964 which was considered as a subgenus of Polleniopsis at the time. The first author recently concluded it should be transferred from the genus Polleniopsis Townsend to Onesia Robineau-Desvoidy (Kurahashi, 1987). The subgenus Melindopsis consists of the three species: menechma Séguy, 1934 (Polleniopsis); menechmoides Chen, 1979 (Bellardia); parafacialis Kurahashi et Tumrasvin, 1979 (Onesia) and khasiensis Senior-White, 1923 (Nitellia).

o.-Head: Eyes bare, holoptic, very narrowly separated on frons by a distance equal to the width of anterior ocellus; frons index 0.03; frontal stripe (frontalia) dark reddish, widened anteriorly, obliterated at narrowest point posteriorly; parafrontalia grayish-silver dusted, darkened toward vertex, with fine rather long black setulae anteriorly, provided with about 8 pairs of ori, uppermost one fine, reclinate; parafacialia gray-silver dusted with rather long, fine bláck setulae on upper part; face fuscous, gray-silver dusted, with a slight indication of a rounded carina at base of antennae; facialia fuscous, more or less brownish laterally, with black setulae on lower $1 / 3$ from vibrissae to antennal bases; medianae reddish brown, bare; vibrissaria brown, with two black setulae in front of genae; vibrissae well developed; epistome not projecting forward, fuscous brown; genae black, gray-dusted, clothed with black hairs; postgenae concolorous with genae, without yellow hairs; occiput concolorous with genae, clothed with black hairs; 2nd antennal segment fuscous black, slightly reddish apically; 3rd antennal segment yellowish brown basally, darkened apically, $2.0 \times$ as long as 2nd; arista fuscous except for apical and basal portions brown, plumose; palpi brownish, with black setulae.

Thorax: Black, covered with bluish gray dusting, with indications of two median and two broad lateral black stripes anteriorly, black haired; humeri concolorous with scutum; postalar calli concolorous with scutum; scutellum concolorous with scutum; postscutellum slightly developed; prosternum hairy; propleura black haired; supraspiracular convexity pubescent, without setulose hairs; hypopleural hairs black; other pleural hairs also black; mesothoracic spiracle small, blackish; metathoracic one also small, blackish; postalar declivity with a few black setulae on central portion; tympanic tuft absent; anterior and posterior para- 

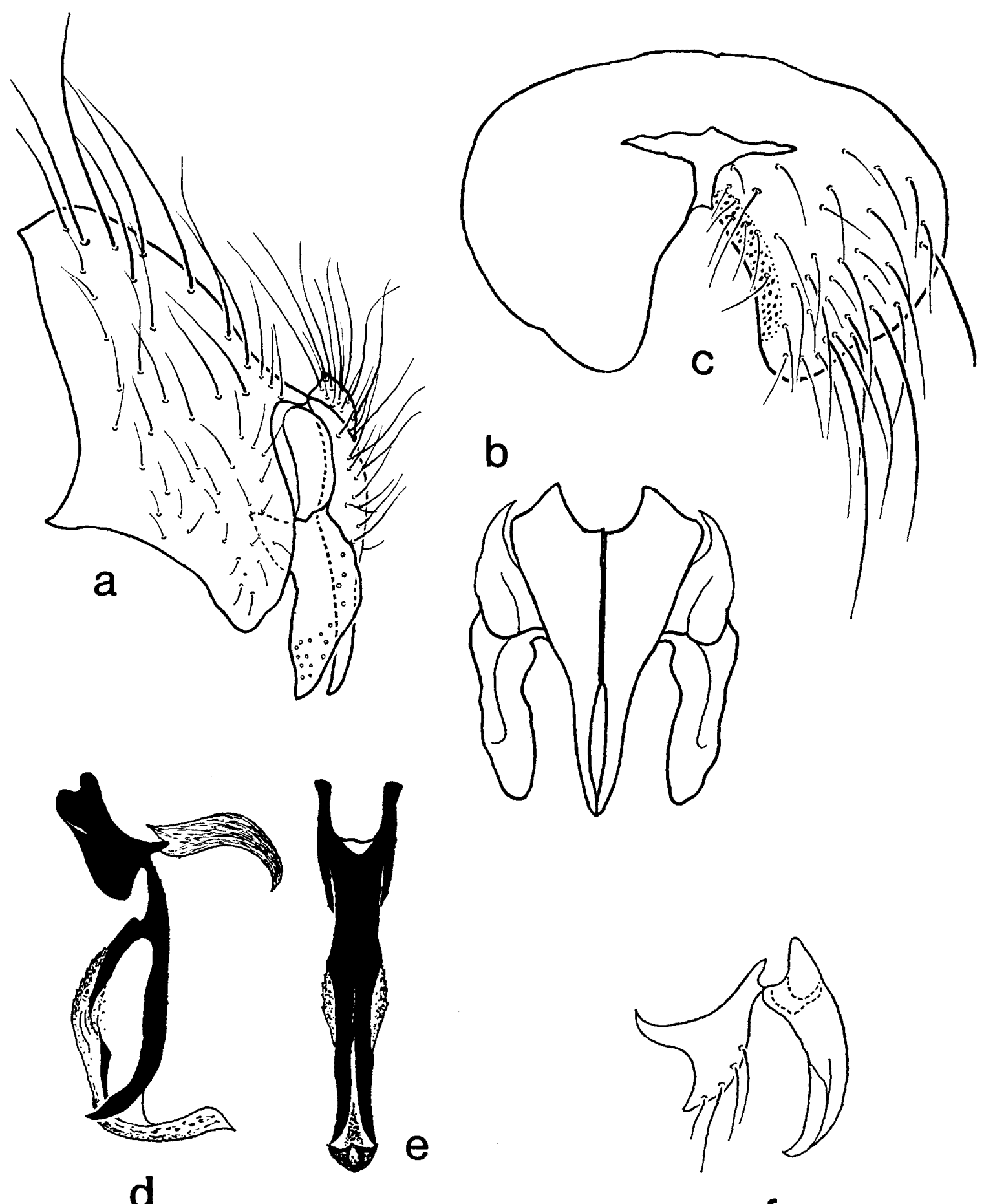

Fig. 1 Onesia khasiensis (Senior-White) n. comb., male hypopygium.

$a$, epandrium, cercus and paralobus, lateral view; b, cerci and paralobi, caudal view;

c, 5th sternite, ventral view; $d$, aedeagus, lateral view; e, aedeagus, posterior view;

$\mathrm{f}$, anterior and posterior parameres, lateral view.

squamal tufts absent. Chaetotaxy; ac 2+3, dc 2-3+3, ia $0+2, h 3$, ph 1-2, prs 1, sa 3-4, pa 2, st 1+1, sc 3+1, $n 2-3, p p 1$, pst 1 .

Wings: Hyaline, very slightly brownish tinged; veins brown; epaulet fuscous; basicosta yellowish brown; subcostal sclerite yellowish brown, pubescent; node of 2nd and 3rd longitudinal veins with 1-2 black setulae above and below; 4th longitudinal vein bent with obtuse 
angle, the section of the 4 th vein from bend to wing edge is straight; cell $R_{5}$ closed; squamae fuscous; thoracic one lobulate, bare on upper surface. Halters pale brown.

Legs: Black, with black hairs; fore tibia with $1 p$ on apical $1 / 3$, without distinct ad; mid tibia with $2 p$; hind tibia with $2 a d, 2 p d$ and 2 well developed $a v$.

Abdomen: Black, bluish-gray dusted, with black median longitudinal stripe on tergites 3-5, black haired; tergites $1+2$ with several lateral marginal bristles; tergite 3 with a row of marginal bristles, the bristles on median part are finer than those on laterals; tergites 4-5 with a row of well developed marginal bristles, tergite 5 with bristly hairs on disc; sternites clothed with rather long black hairs. Hypopygium relatively large, black, subshining; male genitalia as shown in Fig. 1.

9.- The first author examined female type specimens and found them having the open cell $\mathrm{R}_{5}$ and $2+1$ sternopleurals as mentioned in the previous work (Senior-White et al., 1940). These two seem to be characteristic of female, but not of male.

Length: $4.0 \mathrm{~mm}$.

Specimens examined. DHAKA DIV.: $1 \hat{\delta}, 32 \mathrm{~km}$ SW Mymensingh, 30-31. V. 1989, H. Kurahashi (NIHJ).

Bionomics. Nothing is known.

Distribution. India (Assam) and Bangladesh.

\section{Genus Hemipyrellia Townsend}

Hemipyrellia Townsend, 1918, Insecutor Inscit. menst., 6: 154 (Type-species: Hemipyrellia curriei Townsend, 1918 (=Lucilia fernandica Macquart, 1855)).

\section{Hemipyrellia ligurriens (Wiedemann)}

Musca ligurriens Wiedemann, 1830, Aussereurop. zweifl. Insekt., 2: 655.

Length: $\quad 7.0-8.5 \mathrm{~mm}$.

Specimens examined. CHITTAGONG DIV.: 5ô, Sylhet, forest, 21-25. V. 1989, H. Kurahashi (NIHJ) ; $2 \hat{o}$, Cox's Bazar, 5. X. 1988, M. Iwasa (OU); $1 \hat{o}$, Srimongal, 7. X. 1988, M. Iwasa (OU).

Bionomics. H. ligurriens seems to be very common in market sections, gardens in towns and forests. The larva is a scavenger.

Distribution. India, Sri Lanka, Bangladesh, Thailand, Malaysia, Indonesia (Java, Celebes), New Guinea, Australia, China, Korea, Japan, Taiwan, and Philippines.

Genus Hypopygiopsis Townsend

Hypopygiopsis Townsend, 1916, Proc. U. S. natn. Mus., 51: 300 (Type-species: Hypopygiopsis splendens Townsend, 1916 (=Musca fumipennis Walker, 1856)).

\section{Key to the species of Hypopygiopsis}

1. Antennae yellowish orange; facial tomentum golden yellow; tarsi in $\hat{\delta}$ without fringe H. infumata (Bigot)

- Antennae dark reddish brown; facial tomentum silver white; tarsi in $\hat{o}$ with long fringes H. tumrasvini Kurahashi

\section{Hypopygiopsis tumrasvini Kurahashi}

Hypopygiopsis tumrasvini Kurahashi, 1977, Kontyû, 45: 556.

Length: $13.0 \mathrm{~mm}$. 
Specimens examined. CHITTAGONG DIV.: 2⿺, Srimongal, West Bhanugach, reserve forest, 7. X. 1988, M. Iwasa (NIHJ).

Bionomics. Adults are found in dense tropical forests. Oviparous.

Distribution. India, Bangladesh, Thailand, Cambodia, and S. China (Yunnan and Hainan Isl.) .

\section{Hypopygiopsis infumata (Bigot)}

Somomyia infumata Bigot, 1877, Ann. Soc. Ent. Fr., (5) 7: 41.

Length: $9.0-15.0 \mathrm{~mm}$.

Specimens examined. CHITTAGONG DIV: $3 \hat{\delta}$. Srimongal, West Bhanugach, reserve forest, 6. X. 1988, 8. X. 1988, M. Iwasa (NIHJ); $4 \hat{o}$ 5ㅇ, Sylhet, forest, 21-25. V. 1989, H. Kurahashi (NIHJ); 1 \%, Srimongal, 7. X. 1988, M. Iwasa (OU).

Bionomics. Adults are found in dense forests. Oviparous.

Distribution. India, Bangladesh, Burma, Thailand, Laos, Cambodia, Viet Nam, and Ghina (Yunnan, Hainan Isl.).

Genus Lucilia Robineau-Desvoidy

Lucilia Robineau-Desvoidy, 1830, Essai Myod.: 452 (Type-species: Musca caesar Linnaeus, 1758).

\section{Key to the species of Lucilia}

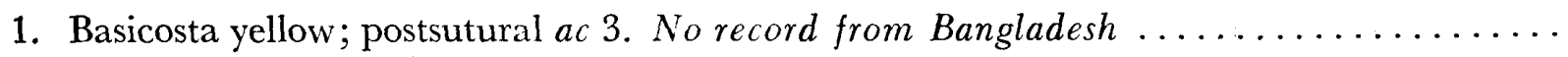
L. cuprina (Wiedemann)

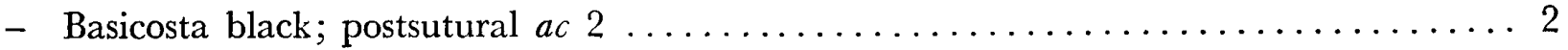

2. Anterior postsutural $a c$ usually more advanced than 2 nd pair of postsutural $d c$; tergites 3-4 without dark marginal band; mid tibia with 1 ad in $\hat{o}$ and $q$. No record from

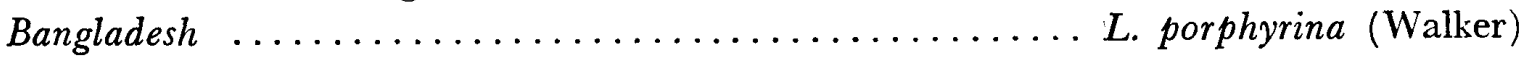

- Anterior postsutural ac level with, or slightly posterior to the 2nd pair of postsutural $d c$; tergites 3-4 with dark marginal band; mid tibia with 1 ad in $\hat{o}, 2$ ad in $\$ \ldots . .3$

3. Alar and thoracic squamae whitish, with a tuft of whitish yellow hairs on outer margin of connection; anterior paramere of male genitalia with 4 hairs $\ldots \ldots \ldots \ldots \ldots$.

L. bismarckensis Kurahashi

- Alar squama fuscous black as in thoracic one, sometimes paler than thoracic one, but usually with a tuft of blackish hairs ................. Lapuensis Macquart

\section{Lucilia bismarckensis Kurahashi}

Lucilia bismarckensis Kurahashi, 1987, Entomol. Soc. Jpn., Occ. Pub., (1) : 46.

Length: $\quad 6.5-10.0 \mathrm{~mm}$.

Specimens examined. DHAKA DIV.: $2 \hat{o} 1 \uparrow, 32 \mathrm{~km}$ SW Mymensingh, forest, 30-31. V. 1989, H. Kurahashi (NIHJ). CHITTAGONG DIV.: 19, Sylhet, forest, 21-25. V. 1989, H. Kurahashi (NIHJ) ; 3 9, Kararhat Forest, 28. V. 1989, H. Kurahashi (NIHJ).

Bionomics. Adults are found in forests.

Distribution. Bangladesh and New Guinea (PNG), Ferg I., New Britain and New Ireland.

\section{Lucilia papuensis Macquart}

Lucilia papuensis Macquart, 1842, Mém. Soc. Sci. Agric. Lille, 1842: 298 (1843: 141). 
Length: $\quad 9.0-10.0 \mathrm{~mm}$.

Specimens examined. CHITTAGONG DIV.: $2 \hat{\delta}$ 1오, Kararhat Forest, 28. V. 1989, H. Kurahashi (NIHJ); $17 \hat{o} 3$ ㅇ, Sylhet, forest, 21-25. V. 1989, H. Kurahashi (NIHJ); $1 \hat{o} 3$ \%, Srimongal, 7. X. 1988, 8. X. 1988, M. Iwasa (OU).

Bionomics. Adults are found in forests.

Distribution. Widely distributed through southeast and east Asia, India, Bangladesh, Thailand, Malaysia, Indonesia, Papua New Guinea, Australia (Queensland, New South Wales), China, Korea, Japan, Taiwan, and Philippines.

Genus Phumosia Robineau-Desvoidy

Phumosia Robineau-Desvoidy, 1830, Essai Myod.: 427 (Type-species: Phumosia abdominalis Robineau-Desvoidy, 1830).

\section{Key to the species of Phumosia}

1. Mesonotum all pale testaceous; hind tibia with $2 p d \ldots . .$. . P. testacea (Senior-White)

- Mesonotum with dark markings; hind tibia with $1 p d$, sometimes $2 p d$ in some rare cases $P$. indica (Surcouf)

\section{Phumosia indica (Surcouf)}

Caiusa indica Surcouf, 1914, Arch. Mus. natn. Hist. nat., Paris, (5)6: 53.

Length: $8.0 \mathrm{~mm}$.

Specimen examined. CHITTAGONG DIV.: 19, Sylhet, forest, 21-25. V. 1989, H. Kurahashi (NIHJ).

Bionomics. Forest species.

Distribution. India, Sri Lanka, Bangladesh, Thailand, Malaysia (Malaya), Indonesia (Java, Celebes), and Taiwan.

\section{Phumosia testacea (Senior-White)}

Caiusa testacea Senior-White, 1923, Spolia zeylan., 12: 310.

Length: $7.5 \mathrm{~mm}$.

Specimen examined. CHITTAGONG DIV.: 19, Sylhet, forest, 21-25. V. 1989, H. Kurahashi (NIHJ).

Bionomics. Forest species.

Distribution. India, Sri Lanka, Bangladesh, Thailand, Malaysia (Malaya), and Philippines (Luzon).

\section{Genus Bengalia Robineau-Desvoidy}

Bengalia Robineau-Desvoidy, 1830, Essai Myod.: 425 (Type-species: Bengalia labiata Robineau-Desvoidy, 1830).

\section{Key to the species of Bengalia}

1. Protuberance below the base of wing pointed; abdomen not tessellated; 4 th sternite with 1 pair of long and strong bristles in $\hat{o}$; body small to medium-sized B. labiata Robineau-Desvoidy

- Protuberance below base of wing rounded; abdomen more or less tessellated; 4th sternite without such bristles; body medium to large-sized ...... B. torosa (Wiedemann) 


\section{Bengalia torosa (Wiedemann)}

Musca torosa Wiedemann, 1819, Zool. Mag., 3: 21.

Length: $15.0 \mathrm{~mm}$.

Specimen examined. DHAKA DIV.: 10, Mymensingh, 28. IX. 1988, M. Iwasa (OU).

Bionomics. Forest species.

Distribution. India (Madras, West Bengal), Sri Lanka, Bangladesh, Thailand, Indonesia (Java), Philippines, Taiwan, and Japan (Iriomote-Jima I.).

\section{Bengalia labiata Robineau-Desvoidy}

Bengalia labiata Robineau-Desvoidy, 1830, Essai Myod.: 426.

Length: $\quad 9.5-10.0 \mathrm{~mm}$.

Specimens examined. CHITTAGONG DIV.: 20, Sylhet, forest, 21-25. V. 1989, H. Kurahashi (NIHJ).

Bionomics. Forest inhabitant.

Distribution. ?India, Bangladesh, Thailand, Malaysia (Malaya), and Indonesia (Sumatra).

\section{Subfamily AMENIINAE}

\section{Tribe Catapicephalini}

Genus Catapicephala Macquart

Catapicephala Macquart, 1851, Mém. Soc. Sci. Agric. Lille, 1850: 210 (1851: 237) (Typespecies: Catapicephala splendens Macquart, 1851).

\section{Catapicephala sp. nr sinica Fan, 1965}

Length: $12.5 \mathrm{~mm}$.

Specimen examined. CHITTAGONG DIV.: 19, Kararhat Forest, 28. V. 1989, H. Kurahashi (NIHJ).

Bionomics. Forest inhabitant.

Distribution. Bangladesh.

\section{Subfamily GHRYSOMYINAE}

\section{Tribe Chrysomyini}

\section{Genus Chrysomya Robineau-Desvoidy}

Chrysomya Robineau-Desvoidy, 1830, Essai Myod.: 444 (Type-species: Chrysomya regalis Robineau-Desvoidy, 1830).

\section{Key to the species of Chrysomya}

1. Mesothoracic spiracle white; facets of male eyes small and uniform $\ldots \ldots \ldots \ldots \ldots$

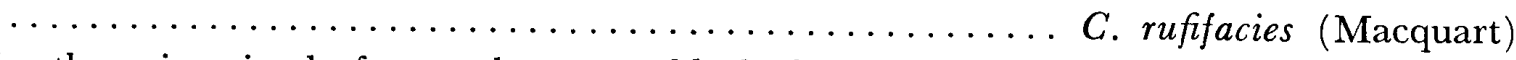

- Mesothoracic spiracle fuscous brown to black; facets on upper $2 / 3$ of male eyes remark-

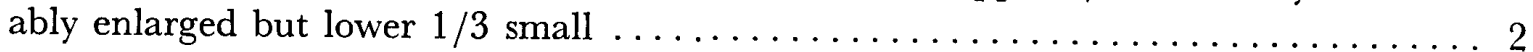

2. Parafacialia and genae yellowish-orange, both covered with yellowish-white hairs; 3rd antennal segment entirely orange $\ldots \ldots \ldots \ldots \ldots \ldots \ldots$. megacephala (Fabricius) 
Vol. 40 Suppl. 1989

- Parafacialia and genae fuscous, both covered with black hairs; 3rd antennal segment

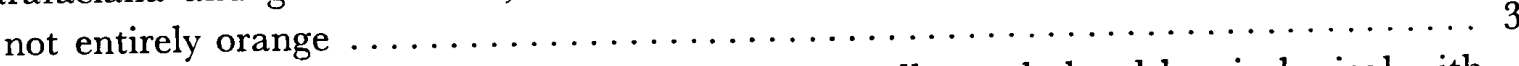

3. Anterior half of alar squama whitish and bare ventrally; male head hemispherical with swollen eyes in profile $\ldots \ldots \ldots \ldots \ldots \ldots \ldots \ldots \ldots \ldots \ldots \ldots \ldots \ldots \ldots \ldots$ chani Kurahashi

- Anterior half of alar squama never pure whitish, covered with dark brown to black hairs ventrally; male head normal in profile $\ldots \ldots \ldots \ldots \ldots \ldots$. . pinguis (Walker)

\section{Chrysomya megacephala (Fabricius)}

Musca megacephala Fabricius, 1794, Syst. Ent., 4: 317.

Chrysomya megacephala: James, 1977: 542.

Length: $\quad 9.0-10.0 \mathrm{~mm}$.

Specimens examined. CHITTAGONG DIV.: $5 \hat{\text { ô }} 2$ \&, Sylhet, forest, 21-25. V. 1989, H. Kurahashi (NIHJ) ; 1 \%, Chittagong, 2. X. 1988, M. Iwasa (OU) ; 1 \%, Srimongal, 7. X. 1988, M. Iwasa (OU).

Bionomics. C. megacephala is very common around houses and in forests in Bangladesh. This species is a common scavenger and sometimes produces myiasis of man and domestic animals. Adults are commonly found on garbage in dumps and very often attracted to decaying meat and human excrement in natural forest.

Distribution. Widely distributed through the Oriental and Australasian Regions and recently introduced into the Afrotropical and Neotropical Regions.

\section{Chrysomya chani Kurahashi}

Chrysomya chani Kurahashi, 1979, J. Med. Entomol., 16: 288.

Length: $\quad 7.0 \mathrm{~mm}$.

Specimen examined. CHITTAGONG DIV.: 1̊̂, Sylhet, forest, 21-25. V. 1989, H. Kurahashi (NIHJ).

Bionomics. Forest inhabitant.

Distribution. Bangladesh, Thailand, Malaysia (Malaya), and Singapore.

\section{Chrysomya pinguis (Walker)}

Lucilia pinguis Walker, 1858, Trans. R. ent. Soc. Lond., (2) 4: 213.

Length: $\quad 6.5-10.5 \mathrm{~mm}$.

Specimens examined. CHITTAGONG DIV.: 4옹, Sylhet, forest, 21-25. V. 1989, H. Kurahashi (NIHJ).

Bionomics. Forest inhabitant.

Distribution. India (Assam, Himachal Pradesh, Madras), Sri Lanka, Bangladesh, Thailand, Malaysia (Malaya), Indonesia (Java, Moluccas), China, Korea, Japan, Taiwan, and Philippines (Palawan, Tawi Tawi).

\section{Chrysomya rufifacies (Macquart)}

Lucilia rufifacies Macquart, 1843, Mém. Soc. Sci. Agric. Lille, 1842: 303 (1843: 146).

Chrysomya rufifacies: James, 1977: 542.

Length: $\quad 7.5-10.0 \mathrm{~mm}$.

Specimens examined. CHITTAGONG DIV.: $2 \hat{\delta} 5$ o, Sylhet, forest, 21-25. V. 1989, H. Kurahashi (NIHJ).

Bionomics. Larvae are primary scavenger but often become predacious and attack other dipteran larvae. This fly is also known to be involved in secondary myiasis.

Distribution. Widely distributed in the Oriental and Australasian Regions. 


\section{Subfamily RHINIINAE}

\section{Key to the genera of Rhiniinae}

1. Arista pectinated; $a c$ and $d c$ not distinguishable from the general ground hairs, the prescutellars at most weekly developed; suprasquamal ridge bare $\ldots \ldots \ldots \ldots \ldots 2$

- Arista pubescent or plumose, not pectinated ...................... 3

2. Hind tibia without a conspicuous row of $a d$, but with 2-3 ad as long as or longer than the tibial diameter; $R_{5}$ open; body slender, parallel-sided; abdomen mostly testaceous $\ldots \ldots \ldots \ldots \ldots \ldots \ldots \ldots \ldots \ldots \ldots \ldots \ldots \ldots \ldots \ldots$ Idiella Brauer et Bergenstamm

- Hind tibia with a conspicuous row of subequal setae on anterodorsal surface, longer than the normal ground hairs, sometimes 2-3 rather strong ad developed among them; fore tibia with $1 \mathrm{pv}$; body rather stout with ovate abdomen and usually of a

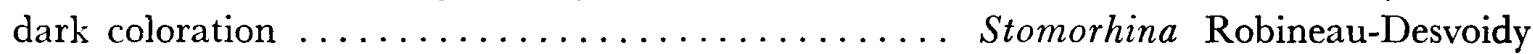

3. Arista plumose, the rays at least as long as the width of 3 rd antennal segment .....4

- Arista pubescent, the longest hairs never exceeding $1.5 \times$ the width of arista at base; fore tibia with $p v$; propleura bare ............ Ryncomyia Robineau-Desvoidy

4. Outer $p h$ absent $\ldots \ldots \ldots \ldots \ldots \ldots \ldots \ldots \ldots \ldots \ldots \ldots \ldots \ldots$ Borborhinia Townsend

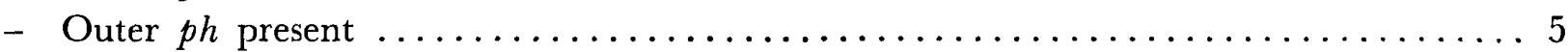

5. Presutural $a c$ absent or indistinct; $d c$ and postsutural $a c$ usually indistinct except for the prescutellars; if 1-2 postsutural ac developed as the prescutellars, then the pro-

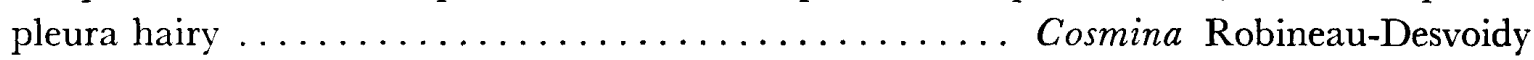

- Presutural $a c$ well developed at least in one pair; $d c$ also well developed; propleura bare

6. Mesopleura with a group of bristles on its upper part; bend of 4th vein regularly curved or angulose; male hypopygium of normal size, scarcely visible seeing the abdomen in profile; female last sternite not projecting posteriorly ........... Isomyia Walker

- Mesopleura without bristle on its upper part next the first notopleural bristle; bend of vein 4 gently curved; male hypopygium and 5 th sternite very strongly developed, altogether almost the same size as the rest of abdomen; female last sternite widely uncovered by the corresponding tergites, its posterior border projecting outwards ....

Strongyloneura Bigot

Genus Cosmina Robineau-Desvoidy

Cosmina Robineau-Desvoidy, 1830, Essai Myod.: 423 (Type-species: Cosmina fuscipennis Robineau-Desvoidy, 1830).

\section{Key to the species of Cosmina}

1. Epaulet reddish brown; propleura hairy; mesonotum faintly with a trace of 4 black longitudinal stripes $\ldots \ldots \ldots \ldots \ldots \ldots \ldots \ldots \ldots \ldots \ldots \ldots \ldots \ldots \ldots \ldots \ldots \ldots$ bicolor (Walker)

- Epaulet black; propleura bare in center; mesonotum with two rather broad longitudinal black stripes $\ldots \ldots \ldots \ldots \ldots \ldots \ldots \ldots \ldots \ldots \ldots \ldots \ldots \ldots \ldots \ldots+$ limbipennis (Macquart)

\section{Cosmina limbipennis (Macquart)}

Idia limbipennis Macquart, 1848, Mém. Soc. Sci. Agric. Lille, 1848: 214 (1847: 54).

Length: $5.0-7.0 \mathrm{~mm}$.

Specimens examined. CHITTAGONG DIV.: 3ᄎ, Kararhat Forest, 28. V. 1989, H. 
Kurahashi (NIHJ) ; $4 \hat{o}$ 5ㅇ, Sylhet, forest, 21-25. V. 1989, H. Kurahashi (NIHJ) ; 20 2 ㅇ, Chandraghona, 50 m, 27. V. 1989, H. Kurahashi (NIHJ); $3 \hat{o}$, Chittagong, 2. X. 1988, M. Iwasa (OU); 1 \%, Srimongal, 8. X. 1988, M. Iwasa (OU).

Bionomics. Adults are found on grasses.

Distribution: India, Bangladesh, Malaysia (Malaya), and Indonesia (Java, Bali).

\section{Cosmina bicolor (Walker)}

Idia bicolor Walker, 1856, J. Proc. Linn. Soc. Lond., Zool. 1: 23.

Length: $\quad 6.0-7.5 \mathrm{~mm}$.

Specimens examined. DHAKA DIV.: $5 \hat{\delta} 3 \%, 32 \mathrm{~km}$ SW Mymensingh, forest, 30-31. V. 1989, H. Kurahashi (NIHJ). CHITTAGONG DIV.: 2ô, Kararhat Forest, 28. V. 1989, H. Kurahashi (NIHJ) ; 1 ô, Sylhet, forest, 21-25. V. 1989, H. Kurahashi (NIHJ); $1 \hat{\delta} 1$ ㅇ, Chandraghona, $50 \mathrm{~m}, 27$. V. 1989, H. Kurahashi (NIHJ).

Bionomics. Adults are found on grasses.

Distribution. India, Bangladesh, Burma, Thailand, Malaysia (Malaya), Indonesia (Sumatra, Java), and Viet Nam.

\section{Genus Strongyloneura Bigot}

Strongyloneura Bigot, 1887, Annls. Soc. ent. Fr., (6)6: Bull.: xiv (Type-species: Strongyloneura prasina Bigot, 1887).

\section{Strongyloneura prolata (Walker)}

Idia prolata Walker, 1860, J. Proc. Linn. Soc. Lond., Zool. 4: 133.

Length: $\quad 5.0-6.5 \mathrm{~mm}$.

Specimens examined. CHITTAGONG DIV.: $3 \hat{8}$ 3jo, Sylhet, forest, 21-25. V. 1989, H. Kurahashi (NIHJ); 3 \%, Srimongal, 7. X. 1988, M. Iwasa (OU).

Bionomics. Adults are found frequently on flowers or blossoms.

Distribution. India, Bangladesh, Burma, Nepal, Japan (Ryukyu), Malaysia (Malaya), and Indonesia (Celebes).

\section{Genus Isomyia Walker}

Isomyia Walker, 1859, J. Proc. Linn. Soc. Lond., Zool. 4: 134 (as subgenus of Musca, Typespecies: Musca delectans Walker, 1859).

\section{Key to the species of Isomyia}

1. Thoracic squama strongly lobulate, its longitudinal diameter subequal to the transverse; body very stout; thoracic and alar squamae fuscous; scutellum with 3 pairs of marginal bristles, equidistant from each other; basicosta black; pleural hairs black and dense.$\ldots \ldots \ldots \ldots \ldots \ldots \ldots \ldots \ldots \ldots \ldots \ldots \ldots \ldots \ldots \ldots \ldots \ldots \ldots \ldots \ldots$ oestarace (Séguy)

- Thoracic squama generally not lobulate, if not so, never reaches the base of scutellum and its longitudinal diameter longer than the transverse; body usually slender ..... 2

2. Basicosta yellow; ac 1+2; abdomen metallic green except for discal part of tergites $1+$ 2-5 coppery, and with black longitudinal median stripe; genae clothed with yellow hairs; 4 th longitudinal vein gently curved; wings with apical cloud very faint ...... I. pseudonepalana Senior-White, Aubertin et Smart

- Basicosta black; postsutural ac usually 1-2+2-3; tergites 3-4 with median black longitudinal stripe or triangular dark spot when viewed from behind $\ldots \ldots \ldots \ldots \ldots . \ldots$ 
3. Mesopleura largely covered with black hairs except for several yellow ones on lower margin, also with a row of long yellow pilosity along posterior margin; notopleura entirely with black setulae; alar and thoracic squamae yellowish brown; wings with apical cloud very faint; $a c 1-2+2$, if $1-2+3$, then anterior postsutural ac fine and located close to the second pair of postsutural $a c \ldots \ldots \ldots \ldots \ldots \ldots \ldots$.

Isomyia sp. nr quadrina Fang et Fan

- Mesopleura largely clothed with yellow hairs on lower $1 / 3$ to $1 / 2$ and along posterior margin before a row of yellow pilosity; notopleura more or less with yellow hairs; wings yellowish hyaline; ac $2+3-4$, three to four postsutural ac well developed and with equidistance or anterior one located far from the second $\ldots \ldots \ldots \ldots \ldots \ldots 4$

4. Thoracic and alar squamae whitish; many black hairs present on upper $1 / 2$ to $2 / 3$ of mesopleura; tibiae fuscous brown; notopleura with black and yellow hairs; ac $2+$ $3-4$; body metallic bluish green in color $\ldots \ldots \ldots \ldots \ldots \ldots \ldots \ldots \ldots \ldots$. . sp. 1

- Thoracic and alar squamae yellowish brown; mesopleura clothed with yellow hairs except for several black ones on median and anterior part of upper half; tibiae yellowish brown, in contrast with fuscous femora; notopleura only with yellow hairs; $a c$ $2+3$; body metallic green with golden or coppery tinge $\ldots \ldots \ldots \ldots \ldots \ldots$ I. sp. 2

\section{Isomyia sp. nr quadrina Fang et Fan, 1985}

Length: $\quad 8.5-11.5 \mathrm{~mm}$.

Specimens examined. DHAKA DIV.: $13 \hat{o} 14$, $32 \mathrm{~km}$ SW Mymensingh, 30-31. V. 1989, H. Kurahashi (NIHJ). CHITTAGONG DIV.: 2 , Sylhet, forest, 21-25. V. 1989, H. Kurahashi (NIHJ).

Bionomics. Adults are found frequently on the blossoms in forests.

Distribution. Bangladesh.

\section{Isomyia pseudonepalana (Senior-White, Aubertin et Smart)}

Strongyloneura pseudonepalana Senior-White, Aubertin et Smart, 1940, Fauna Br. India, Dipt., 6: 162 .

Length: $\quad 6.5-9.0 \mathrm{~mm}$.

Specimens examined. CHITTAGONG DIV.: 3\%, Sylhet, forest, 21-25. V. 1989, H. Kurahashi (NIHJ) ; 1 \%, Srimongal, 7. X. 1988, M. Iwasa (OU).

Bionomics. Adults are frequently found on the blossoms in forests.

Distribution. India (Assam), Sri Lanka, Nepal, and Bangladesh.

\section{Isomyia oestaracea (Séguy)}

Pachycosmina oestracea Séguy, 1934, Encycl. ent. (B) II, Dipt., 7: 18.

Length: $10.0-10.5 \mathrm{~mm}$.

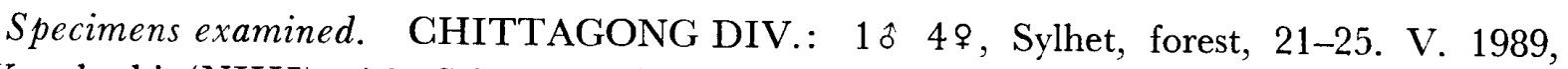
H. Kurahashi (NIHJ) ; 1 \%, Srimongal, 7. X. 1988, M. Iwasa (OU). DHAKA DIV.: 1 \%, Mymensingh, 30-31. V. 1989, H. Kurahashi (NIHJ).

Bionomics. Adults are frequently found on the blossoms in forests.

Distribution. India, Bangladesh, Malaysia (Malaya), Laos, Indonesia (Java), and China.

\section{Isomyia sp. 1}

Length: $9.0-10.5 \mathrm{~mm}$.

Specimens examined. CHITTAGONG DIV.: 1क, Kararhat Forest, 28. V. 1989, H. Kurahashi $(\mathrm{NIHJ}) ; 61$ \%, Sylhet, forest, 21-25. V. 1989, H. Kurahashi (NIHJ). DHAKA 
DIV.: $2 \hat{o} 3$ ?, $32 \mathrm{~km}$ SW Mymensingh, 30-31. V. 1989, H. Kurahashi (NIHJ).

Bionomics. Adults are frequently found on the blossoms in forests.

Distribution. Bangladesh.

\section{Isomyia sp. 2}

Length: $\quad 7.5-9.0 \mathrm{~mm}$.

Specimens examined. CHITTAGONG DIV.: 34\%, Sylhet, forest, 21-25. V. 1989, H. Kurahashi $(\mathrm{NIHJ})$; 2 \%, Kararhat Forest, 28. V. 1989, H. Kurahashi (NIHJ). DHAKA DIV.: 2\& 8ㅇ, $32 \mathrm{~km}$ SW Mymensingh, 30-31. V. 1989, H. Kurahashi (NIHJ).

Bionomics. Adults are frequently found on the blossoms in forests.

Distribution. Bangladesh.

\section{Genus Rhyncomya Robineau-Desvoidy}

Rhyncomya Robineau-Desvoidy, 1830, Essai Myod.: 424 (Type-species: Musca felina Fabricius, 1794).

\section{Rhyncomya setipyga Villeneuve}

Rhyncomya setipyga Villeneuve, 1929, Bull. Annls. Soc. ent. Belg., 69: 62.

Length: $\quad 5.0-8.0 \mathrm{~mm}$.

Specimens examined. CHITTAGONG DIV.: $2 \hat{o} 5$ \% , Chandraghona, $50 \mathrm{~m}, 27 . \mathrm{V} .1989$, H. Kurahashi (NIHJ); $2 \hat{\delta}$, Kararhat Forest, 28. V. 1989, H. Kurahashi (NIHJ); 2 , Sylhet, forest, 21. V. 1989, H. Kurahashi (NIHJ).

Bionomics. Adults are frequently found on the blossoms and often attracted to the honeydew excreted by aphids.

Distribution. Nepal, Bangladesh, Japan (Ryukyu), Taiwan, and Philippines (Palawan). Genus Stomorhina Rondani

Stomorhina Rondani, 1861, Dipt. Ital. Prodromus, 4: 9 (Type-species: Musca lunata Fabricius, 1805).

\section{Stomorhina discolor (Fabricius)}

Musca discolor Fabricius, 1794, Ent. Syst., 4: 320.

Stomorhina discolor: James, 1977: 554.

Length: $\quad 5.0-7.0 \mathrm{~mm}$.

Specimens examined. CHITTAGONG DIV.: 1 f 7 ㅇ, Sylhet, forest, 21-25. V. 1989, H. Kurahashi (NIHJ) ; $1 \hat{o}$, Chandraghona, $50 \mathrm{~m}$, secondary forest, 27. V. 1989, H. Kurahashi (NIHJ). DHAKA DIV.: $3 \hat{\delta} 3$ $9,32 \mathrm{~km}$ SW Mymensingh, forest, 30-31. V. 1989, H. Kurahashi (NIHJ).

Bionomics. Adults are frequently found on flowers or blossoms.

Distribution. Entire Oriental Region.

\section{Genus Idiella Brauer et Bergenstamm}

Idiella Brauer et Bergenstamm, 1889, Denkschr. Akad. Wiss. Wien, 56: 154 (Type-species: Idia mandarina Wiedemann, 1830).

\section{Key to the species of Idiella}

1. Basicosta black; occipital dilatation, mesopleura and sternopleura with distinct piliferous spots I. divisa (Walker) 
- Basicosta brown; occipital dilatation, mesopleura and sternopleura without distinct piliferous spots; 2nd antennal segment reddish; mid tibia with $2 p$ and with a brush of hairs in $\hat{\delta}$; male frons usually broader than the width of ocellar triangle I. mandarina (Wiedemann)

\section{Idiella divisa (Walker)}

Idia divisa Walker, 1861, J. Proc. Linn. Soc. Lond., Zool. 5: 267.

Length: $\quad 6.0-7.5 \mathrm{~mm}$.

Specimens examined. CHITTAGONG DIV.: 3. 1 i , Sylhet, forest, 21-25. V. 1989, H. Kurahashi (NIHJ).

Bionomics. Adults are attracted to animal matter in forests.

Distribution. Inida, Bangladesh, Malaysia (Malaya), Viet Nam, and Indonesia (Celebes).

\section{Idiella mandarina (Wiedemann)}

Idia mandarina Wiedemann, 1830, Aussereurop. zweifl. Insekt., 2: 350.

Length: $9.5-10.0 \mathrm{~mm}$.

Specimens examined. DHAKA DIV.: $2 \hat{o}, 32 \mathrm{~km}$ SW Mymensingh, forest, 30-31. V. 1989, H. Kurahashi (NIHJ).

Bionomics. Adults are frequently found on the blossoms in forests.

Distribution. India (West Bengal), Sri Lanka, Bangladesh, Burma, Thailand, Malaysia (Malaya, Borneo), Indonesia (Sumatra, Timor), Key Is., S. China, and Taiwan.

\section{Genus Borbororhinia Townsend}

Borbororhinia Townsend, 1917, Rec. Indian Mus., 13: 188 (Type-species: Borbororhinia pubescens Townsend, 1917 (=Idia bivittata Walker, 1856)).

\section{Borbororhinia bivittata (Walker)}

Idia bivittata Walker, 1856, J. Proc. Linn. Soc. Lond., Zool. 1: 128.

Length: $6.5 \mathrm{~mm}$.

Specimen examined. CHITTAGONG DIV.: 19, Sylhet, forest, 21-25. V. 1989, H. Kurahashi (NIHJ).

Bionomics. Adults are attracted to animal matter in forests.

Distribution. India (Kerala), Sri Lanka, Bangladesh, Laos, Malaysia (Malaya, Borneo), Indonesia (Java, Moluccas, Buru), Taiwan, and Philippines (Mindoro, Palawan, Tawi Tawi).

\section{Acknowledgements}

Thanks are due to Dr. K. Kamimura (chief of the survey), Toyama Medical and Pharmaceutical University, Toyama for allowing the authors to carry out the present study and to other members of the project team for their kind assistance in the field survay.

\section{REFERENCES}

James, M. T. (1977): Family Calliphoridae. In: A catalog of the Diptera of the Oriental Region. Vol. III. Suborder Cyclorrhapha (excluding Division Aschiza) (ed., Delfinado, M. D. and Hardy, D. E.), pp. 526-556, University Press of Hawaii, Honolulu.

Kurahashi, H. (1987): Blow flies of medical importance in Taiwan (Diptera: Calliphoridae) 1, Tribes Calliphorini and Luciliini. Sieboldia, Suppl.: 47-59.

Senior-White, R. A., D. Aubertin and J. Smart (1940): The Fauna of British India, Including the Re- 
Vol. 40 Suppl. 1989

mainder of the Oriental Region, Diptera, Vol. V1, Family Calliphoridae, xii +288 pp., Taylor \& Francis, Ltd., London.

\section{摘要}

\section{バングラデシュの衛生上重要なクロバエ}

1988年と1989年に行われた文部省海外学術調査の際，バングラデシュで採集されたクロバエは15属 28種であった。採集された標本を材料にバングラデシュ産クロバエの検索表を作った．このうち， Isomyia 属の 3 種と Catapicephala 属の 1 種は同定末了として残った. 東洋区に広く分布することが 知られている Chrysomya megacephala (Fabricius), C. rufifacies (Macquart), Stomorhina discolor (Fabricius) を除く21種はすべてバングラデシュと明記された記録としてははじめてであった。 Onesia khasiensis (Senior-White, 1923) n. comb. については, これまで雄についての記載がなかったので, 今回採集された 1 に 基づいて外部形態の記載を行い, 外部生殖器を図示した. 本種の所属はこれま で Pollenia 属に含まれていたが, 雄の交尾器の形態から明らかにOnesia 属のものと判断されるの で, Onesia 属の Melindopsis 亜属に移した. 